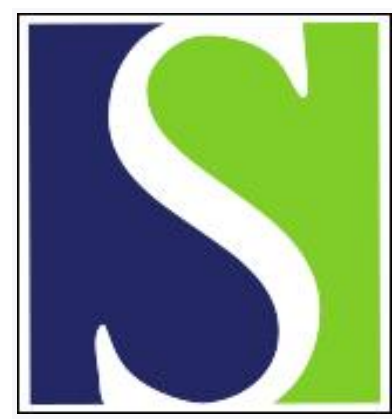

Scand J Work Environ Health 2007;33(5):325-335

https://doi.org/10.5271/sjweh.1153

Issue date: 31 Oct 2007

Estimating the relative risk of pancreatic cancer associated with exposure agents in job title data in a hierarchical Bayesian meta-analysis

by Ojajärvi A, Partanen T, Ahlbom A, Hakulinen T, Kauppinen T, Weiderpass $\mathrm{E}$, Wesseling $\mathrm{C}$

Affiliation: Finnish Institute of Occupational Health, Good Practices and Competence, Topeliuksenkatu 41 a A, 00250 Helsinki, Finland. anneli.ojajarvi@ttl.fi

Refers to the following texts of the Journal: 1996;22(1):14-26 1995;21(3):179-190

Key terms: exposure agent; hierarchical Bayesian meta-analysis; hierarchical method; job title; job-exposure matrix; Markov chain Monte Carlo simulation; MCMC; occupational exposure; pancreatic cancer; pancreatic neoplasms; relative risk; review

This article in PubMed: www.ncbi.nlm.nih.gov/pubmed/17973058 


\title{
Estimating the relative risk of pancreatic cancer associated with exposure agents in job title data in a hierarchical Bayesian meta-analysis
}

\author{
by Anneli Ojajärvi, MSc, ${ }^{1}$ Timo Partanen, PhD, ${ }^{2}$ Anders Ahlbom, PhD, ${ }^{3}$ Timo Hakulinen, PhD, ${ }^{4}$ Timo \\ Kauppinen, $\mathrm{PhD},{ }^{1}$ Elisabete Weiderpass, MD, ${ }^{3,5,6}$ Catharina Wesseling, MD $^{2}$
}

\begin{abstract}
Ojajärvi A, Partanen T, Ahlbom A, Hakulinen T, Kauppinen T, Weiderpass E, Wesseling C. Estimating the relative risk of pancreatic cancer associated with exposure agents in job title data in a hierarchical Bayesian meta-analysis. Scand J Work Environ Health 2007;33(5):325-335.
\end{abstract}

\begin{abstract}
Objectives The study demonstrates the application of a hierarchical Bayesian meta-analysis of epidemiologic studies that show an association between pancreatic cancer risk and job titles, using a job-exposure matrix to estimate risks for occupational exposure agents.

Methods Altogether 261 studies published from 1969 through 1998 on pancreatic cancer and job titles were identified. When proportional studies were excluded, 77 studies were informative for 9 selected occupational agents. These studies included more than 3799 observed pancreatic cancer cases. Hierarchical Bayesian models were used for job titles (lower-level data) and agents (higher-level data), the latter from a Finnish job-exposure matrix. Non-Bayesian random effects models were applied for job titles to check consistency with the Bayesian results.

Results The results suggest that occupational exposures to chlorinated hydrocarbon compounds may increase the risk of pancreatic cancer; the meta-relative risk (MRR) was 2.21 [95\% credible interval (CrI) 1.31-3.68]. A suggestive weak excess was found for exposure to insecticides (MRR 1.95, 95\% CrI 0.51-7.41).

Conclusions Hierarchical models are applicable in meta-analyses when studies addressing the agent(s) under study are lacking or are very few, but several studies address job titles with potential exposure to these agents. Hierarchical meta-analytic models involving durations and intensities of exposure to occupational agents from a job-exposure matrix should be developed.
\end{abstract}

Key terms hierarchical method; job-exposure matrix, job title; Markov chain Monte Carlo simulation; occupational exposure; pancreatic neoplasms.

Pancreatic cancer is a highly fatal malignancy whose etiology is mostly unknown. An estimated 216000 new cases of pancreatic cancer occurred globally in 2000 (1), and it represents the fifth leading cause of cancer deaths in developed countries. The only established common risk factors of pancreatic cancer are tobacco smoking and type II diabetes mellitus (2-4). Results of epidemiologic studies that have linked industries and jobs with excess pancreatic cancer are heterogeneous and inconsistent, and exposures shared by high-risk jobs are hard to identify (5-9). Most of the occupational chemical agents that have been found to be associated with an excess risk of pancreatic cancer in epidemiologic studies emerged in one study only. A previous meta-analysis (10) of studies of occupational agents found significant excesses for chlorinated hydrocarbon solvents and nickel and nickel compounds. After the collection of data for this meta-analysis was finished (May 1998), Kernan et al (7) and Hoppin et al (11) reported significant excesses for chlorinated hydrocarbon solvents, and Weiderpass et al (12) reported significant excesses for nickel and nickel compounds. Other occupational agents with reported excess risks of pancreatic cancer in at least two epidemiologic studies are asbestos, chromium and chromium

1 Finnish Institute of Occupational Health, Good Practices and Competence, Helsinki, Finland.

2 Universidad Nacional, Heredia, Costa Rica.

3 Karolinska Insitutet, Department of Medical Epidemiology and Biostatistics, Stockholm, Sweden.

$4 \quad$ Finnish Cancer Registry, Helsinki, Finland.

5 The Cancer Registry of Norway, Oslo, Norway.

6 Samfundet Folkhälsan, Folkhälsan Research Centre, Department of Genetic Epidemiology, Helsinki, Finland.

Correspondence to: Anneli Ojajärvi, Finnish Institute of Occupational Health, Good Practices and Competence, Topeliuksenkatu 41 a A, 00250 Helsinki, Finland. [E-mail: anneli.ojajarvi@ttl.fi] 
compounds, ionizing radiation, low-frequency electromagnetic fields, pesticides, and polycyclic aromatic hydrocarbons.

McElvenny et al (13) reviewed meta-analyses of occupational epidemiology in general. They identified 66 papers from 1975 to October 2001. Only one study used Bayesian methods (14). Our literature search from PubMed for the period October 2001 to December 2005 did not identify a single Bayesian meta-analysis of occupational epidemiology.

Biggerstaff et al (14) compared classical and Bayesian meta-analyses in studies of lung cancer and passive smoking in the workplace. Tweedie et al (15) applied Bayesian models to a meta-analysis of environmental tobacco smoking and lung cancer studies for nonsmoking women both in the workplace and at home. Wraith $\&$ Mengersen (16) recently published a hierarchical Bayesian meta-analysis of lung cancer and interaction with asbestos and smoking.

Job-exposure matrices were developed to translate job titles into occupational agents. They have been applied in several occupational studies based on individual data, especially if exposure assessment at the individual level was not available. Kauppinen et al (17) applied a British job-exposure matrix (18) in a Finnish case-control study of pancreatic cancer. Alguacil et al (19) used a Finnish job-exposure matrix (FINJEM) (20), which provides estimates for prevalence, intensity, and their combination, in a Spanish case-control study of pancreatic cancer. Kogevinas et al (21) used FINJEM and combined 11 European case-control studies of bladder cancer. Gilks \& Richardson (22) applied a job-exposure matrix and hierarchical Bayesian methods to individual job title data using logistic regression models. Their results from three models, two logistic regression models and one Bayesian logistic regression model, suggested that Bayesian models may overestimate the results, although, on the average, ecological or aggregated bias weakens the relative risks.

Hierarchical models in a meta-analysis allow for the estimation of both the parameters of the individual studies at the first level and aggregated parameters at higher levels. Witte et al (23-25) applied semi-Bayesian hierarchical regression models in a study of dietary exposures and breast cancer to case-control data. In an analogous manner, we applied hierarchical Bayesian methods in a meta-analysis for job titles and pancreatic cancer on the basis of studies that addressed job titles only. The second-level agent data were provided by a job-exposure matrix. We wanted to examine how Bayesian models perform in a meta-analytic setting when compared with conventional methods, using hierarchical data and hierarchical models. We also attempted to evaluate the feasibility of the use of job-exposure matrices in metaanalyses.

\section{Material and methods}

We searched cohort, linkage, proportional, and casecontrol studies in any language with data on job titles, occupational exposures, and pancreatic cancer in Medline, Toxline, and Cancerlit databases for the period January 1969 - May 1998. Reference lists of the identified studies provided additional studies.

Of the 1902 studies identified, 373 remained after the exclusion of studies that did not report on pancreatic cancer or provide data for any job title or occupational agent, reviews, reports earlier than the most recent update, studies with insufficient data for the meta-analysis or with data contained in another study that was included, and studies on job-agent categories too broad or outside our list of job titles or agents. Of the 373 selected studies, 112 were agent-specific studies that provided risk estimates directly for one or several of 25 chemical or physical workplace agents. Meta results for these studies have been reported elsewhere (10). This paper was based on the rest of the 261 job-title studies that did not provide direct agent data. The list of job titles covered 150 entries in the Finnish social status categories 3,4 , and 5 . The upper categories 1 and 2 were excluded from the analyses because of minimal or no exposures.

Standardized data extraction forms covered the characteristics of the study (publication year, country, study type, case definition, source of cases, reference population, selection of control participants, follow-up period, loss to follow-up, response rates, sources of exposure or job data, time reference for exposure or job, risk measure, cohort admission, lag periods, exposure-response, job title coding applied), risk estimates, and numbers of exposed cases. Using the standard form, five epidemiologists extracted relevant estimates of relative risk and the aforementioned items. The most unbiased relative risk estimates were sought. Thus estimates adjusted for social class were preferred over those not adjusted for social class. Estimates adjusted for at least known risk factors for pancreatic cancer (age, gender, diabetes mellitus, tobacco smoking) and those closest to a 20-year latency period were chosen, if available. When confidence intervals were not provided, they were recovered using Byar's approximation (26) for cohort data and using the variance of the log of the odds ratio for case-control data. Two authors double checked all of the extraction forms and corrected for any inconsistencies.

After the studies that were not informative with respect to the nine selected occupational agents, as based on the FINJEM and proportional studies because of poor quality were excluded from 261 job title studies, 77 studies (27-103) remained, including 27 job titles and more than 3799 pancreatic cancer cases. The nine selected agents represented those with meta-relative risks 
for pancreatic cancer exceeding 1.1 in a previous metaanalysis (10). They were aliphatic and alicyclic hydrocarbon solvents, chlorinated hydrocarbon compounds, chromium and chromium compounds, fungicides, insecticides, nickel and nickel compounds, polycyclic aromatic hydrocarbons, silica dust, and wood dust. Of the 77 studies, 52 were cohort studies representing 67 risk estimates, 19 were record-linkage studies that were entirely based on linkage with extraneous databases on job titles and occupations (eg, census) and on outcomes (eg, death records) representing 69 risk estimates, and 6 were case-control studies representing 15 risk estimates (table 1).

The data for most of the risk estimates came from northern Europe $(\mathrm{N}=56)$, closely followed by North America $(\mathrm{N}=48)$, and less closely by western $(\mathrm{N}=17)$, southern $(\mathrm{N}=14)$ and central Europe $(\mathrm{N}=8)$, Asia $(\mathrm{N}=3)$, Oceania $(\mathrm{N}=3)$ and mixed western Europe and North America $(\mathrm{N}=2)$. There were no studies from eastern Europe, Central or South America, the Caribbean, or Africa. The annual number of studies increased considerably during 1969-1998 (7 risk estimates during 1969-1979, 40 risk estimates during 1980-1989, and 104 risk estimates during 1990-1998). More than threefourths of the populations were male. Most of the studies addressed mortality, death records usually providing the diagnosis.

At the higher level of data, a FINJEM provided proportions of exposed workers during the period 19601985 for the selected nine occupational agents in 27 job titles. Because the proportions exposed to chromium and chromium compounds and nickel and nickel compounds were nearly identical, we used their means in the hierarchical Bayesian models (table 2). To reduce misclassification and ecological bias, a $20 \%$ proportion of exposed workers was used as the cutpoint for exposure (104). The exposure assessment period 1960-1985 was selected on the assumption that most of the workers had been exposed during this period.

In the hierarchical Bayesian models, we included the following five dichotomized covariates: study type (case-control versus cohort), publication year (cutpoint 1990), diagnosis of pancreatic cancer (histological versus others), country (Denmark, Finland, Norway and Sweden versus others), and time reference for job title (longitudinal versus others).

\section{Statistical methods}

The DerSimonian and Laird random effects model (105) for a meta-analysis without covariates was applied to each of the 27 job titles to compare estimates of job titles with those of a hierarchical Bayesian meta-analysis. A $\chi^{2}$ test of heterogeneity was performed for each job title. Both Begg's adjusted rank correlation test (106) and
Egger's regression asymmetry test (107) were performed to formally test for publication bias.

In the hierarchical Bayesian meta-analyses, we calculated both the aggregated estimates of occupational agents using job title estimates from each study and the aggregated estimates for the job titles themselves. We used Bayesian models for job titles (lower level, study data) and agents (higher-level FINJEM data). This model is semi-ecological in the sense that the outcome data from the studies were based on individual data, while the agents were assessed at the job title-agent levels $(108,109)$.

Table 1. Characteristics of the pancreatic cancer studies and the risk estimates included according to job titles. $(\mathrm{C}-\mathrm{C}=\mathrm{Case}-\mathrm{control}$ study, $\mathrm{COH}=$ cohort study, $\mathrm{R}-\mathrm{L}=$ record-linkage study, $\mathrm{OR}=$ odds ratio, $\mathrm{SIR}=$ standardized incidence ratio, $\mathrm{SMR}=$ standardized mortality ratio, $\mathrm{RR}=$ rate ratio)

\begin{tabular}{|c|c|c|}
\hline Job title a & $\begin{array}{l}\text { Number and } \\
\text { type of studies } \\
\text { included }\end{array}$ & $\begin{array}{l}\text { Number of risk } \\
\text { estimates } \\
\text { included }\end{array}$ \\
\hline Asphalt workers (27-29) & $2 \mathrm{COH}, 1 \mathrm{R}-\mathrm{L}$ & $3 \mathrm{SIR}$ \\
\hline Bench carpenters (28) & $1 \mathrm{COH}$ & $1 \mathrm{SMR}$ \\
\hline Bricklayers $(27,28,30,31)$ & $1 \mathrm{COH}, 3 \mathrm{R}-\mathrm{L}$ & $2 \mathrm{SIR}, 1 \mathrm{SMR}, 1 \mathrm{RR}$ \\
\hline Cabinetmakers $(31,32)$ & $1 \mathrm{COH}, 1 \mathrm{R}-\mathrm{L}$ & $1 \mathrm{SMR}, 1 \mathrm{RR}$ \\
\hline Cement workers $(28,34)$ & $2 \mathrm{COH}$ & $2 \mathrm{SIR}$ \\
\hline Concrete shutters $(28,34)$ & $2 R-L$ & $1 \mathrm{SIR}, 1 \mathrm{SMR}$ \\
\hline $\begin{array}{l}\text { Construction carpenters } \\
(27,28,31,32)\end{array}$ & $2 \mathrm{COH}, 2$ & $2 \mathrm{SIR}, 1 \mathrm{SMR}, 1 \mathrm{RR}$ \\
\hline Construction workers $(28,35-37)$ & $\begin{array}{l}2 \mathrm{C}-\mathrm{C}, 1 \mathrm{COH} \\
1 \mathrm{R}-\mathrm{L}\end{array}$ & 2 OR, 2 SIR, 1 RR \\
\hline Electric & $2 \mathrm{R}-\mathrm{L}$ & $1 \mathrm{SIF}$ \\
\hline Farmers $(28,31$ & $\begin{array}{l}4 \mathrm{C}-\mathrm{C}, 3 \mathrm{COH} \\
8 \mathrm{R}-\mathrm{L}\end{array}$ & $\begin{array}{l}6 \mathrm{OR}, 9 \\
2 \mathrm{RR}\end{array}$ \\
\hline mblers (28) & $1 \mathrm{R}-\mathrm{L}$ & $1 \mathrm{SIR}$ \\
\hline Foundry workers $(50-55)$ & $5 \mathrm{COH}, 1 \mathrm{R}-\mathrm{L}$ & $1 \mathrm{SIR}, 7$ SMR \\
\hline workers & $3 \mathrm{COH}, 4 \mathrm{R}-\mathrm{L}$ & $3 \mathrm{SIR}, 4 \mathrm{SMR}, 1 \mathrm{RR}$ \\
\hline $\begin{array}{l}\text { Mach } \\
(31,\end{array}$ & $\mathrm{OH}$ & 1 \\
\hline $\begin{array}{l}\text { Metal } \\
(28,3\end{array}$ & $\begin{array}{l}1 \mathrm{C}-\mathrm{C}, 2 \mathrm{COH} \\
3 \mathrm{R}-\mathrm{L}\end{array}$ & $\begin{array}{l}1 \mathrm{OR}, 1 \mathrm{SIR}, 2 \\
\text { SMRs, } 2 \text { RR }\end{array}$ \\
\hline $\begin{array}{l}\text { Metal smeltin } \\
(28,35,50,6\end{array}$ & $15 \mathrm{COH}, 2 \mathrm{R}-\mathrm{L}$ & 6 SIR, 9 SMR, 2 R \\
\hline Miners $(28,31,35,78-89)$ & $12 \mathrm{COH}, 3 \mathrm{R}-\mathrm{L}$ & $\begin{array}{l}1 \mathrm{SIR}, 12 \mathrm{SMR}, \\
2 \mathrm{RR}\end{array}$ \\
\hline $\begin{array}{l}\text { Painters }(27,28, \\
34,50,90-92)\end{array}$ & $2 \mathrm{COH}$ & $\begin{array}{l}1 \mathrm{OR}, 4 \mathrm{SIR}, 4 \mathrm{SMR} \text {, } \\
1 \mathrm{RR}\end{array}$ \\
\hline $\begin{array}{l}\text { Plywood and fiberboard workers } \\
(28,93)\end{array}$ & $1 \mathrm{COH}, 1 \mathrm{R}-\mathrm{L}$ & $1 \mathrm{SIR}, 1 \mathrm{SMR}$ \\
\hline $\begin{array}{l}\text { Printers and pressmen } \\
(28,30,31,35,37,94-98)\end{array}$ & $\begin{array}{l}1 \mathrm{C}-\mathrm{C}, 4 \mathrm{COH} \\
5 \mathrm{R}-\mathrm{L}\end{array}$ & $\begin{array}{l}1 \mathrm{OR}, 5 \mathrm{SIR}, 4 \mathrm{SMR}, \\
2 \mathrm{RR}\end{array}$ \\
\hline Sawyers $(52,99)$ & $1 \mathrm{COH}, 1 \mathrm{R}-\mathrm{L}$ & $1 \mathrm{SIR}, 1 \mathrm{SMR}$ \\
\hline Sheet metal workers ( & $1 \mathrm{COH}, 2 \mathrm{R}-\mathrm{L}$ & $2 \mathrm{SIR}, 1 \mathrm{RR}$ \\
\hline Smiths (31) & $1 \mathrm{R}-\mathrm{L}$ & $1 \mathrm{RR}$ \\
\hline Stone cutters (27) & $1 \mathrm{COH}$ & $1 \mathrm{SIR}$ \\
\hline Timbermen and lumbermen $(28,36)$ & $1 \mathrm{C}-\mathrm{C}, 1 \mathrm{R}-\mathrm{L}$ & $10 \mathrm{R}, 1 \mathrm{SIR}$ \\
\hline $\begin{array}{l}\text { Turners and toolmakers }(28,31 \text {, } \\
50,100)\end{array}$ & $1 \mathrm{COH}, 3 \mathrm{R}-\mathrm{L}$ & 1 SIR, 2 SMR, 1 RR \\
\hline $\begin{array}{l}\text { Wood working machine operators } \\
(28,34,35,37,93,101-103)\end{array}$ & $\begin{array}{l}2 \mathrm{C}-\mathrm{C}, 4 \mathrm{COH} \\
2 \mathrm{R}-\mathrm{L}\end{array}$ & $\begin{array}{l}2 \mathrm{OR}, 2 \mathrm{SIR}, 3 \mathrm{SMR}, \\
1 \mathrm{RR}\end{array}$ \\
\hline
\end{tabular}

a The reference numbers pertaining to the job title studies are given in parentheses. 
Table 2. Part of a job-exposure matrix [the Finnish job-exposure matrix (20)] used in hierarchical Bayesian models 1 and 2.

\begin{tabular}{|c|c|c|c|c|c|c|c|c|}
\hline \multirow[t]{2}{*}{ Job title } & \multicolumn{8}{|c|}{ Proportion exposed to chemical agent } \\
\hline & $\begin{array}{l}\text { Aliphatic } \\
\text { and alicyclic } \\
\text { hydrocarbon } \\
\text { solvents }\end{array}$ & $\begin{array}{l}\text { Chlorinated } \\
\text { hydro- } \\
\text { carbon } \\
\text { compounds }\end{array}$ & Fungicides & Insecticides & $\begin{array}{l}\text { Nickel, } \\
\text { chromium } \\
\text { and nickel } \\
\text { and chromium } \\
\text { compounds }\end{array}$ & $\begin{array}{l}\text { Polycyclic } \\
\text { aromatic } \\
\text { hydro- } \\
\text { carbons }\end{array}$ & $\begin{array}{l}\text { Silica } \\
\text { dust }\end{array}$ & $\begin{array}{c}\text { Wood } \\
\text { dust }\end{array}$ \\
\hline Construction carpenters & $-{ }^{a}$ & - & - & - & - & - & 0.76 & 1 \\
\hline Electric machine operators & - & - & - & - & - & - & 0.29 & - \\
\hline Farmers & - & - & 0.25 & - & - & - & - & - \\
\hline Fitters and assemblers & - & - & - & - & 0.42 & - & - & - \\
\hline Foundry workers & - & - & - & - & 0.25 & - & 0.44 & - \\
\hline Laundry and dry cleaning workers & - & 0.39 & - & - & - & - & - & - \\
\hline Machine and engine mechanics & - & - & - & - & 0.33 & 1 & - & - \\
\hline Metal plating workers & - & 0.92 & - & - & 0.46 & - & - & - \\
\hline Metal smelting furnacemen & - & - & - & - & 0.41 & 1 & 1 & - \\
\hline Painters & 0.98 & - & - & - & - & - & - & - \\
\hline Plywood and fiberboard workers & - & - & 0.33 & 0.33 & - & - & - & 0.66 \\
\hline Printers and pressmen & 0.33 & 0.20 & - & - & - & - & - & - \\
\hline Sawyers & - & - & 0.45 & - & - & - & - & 1 \\
\hline Sheet metal workers & - & - & - & - & 0.38 & - & - & - \\
\hline Stone cutters & - & - & - & - & - & - & 0.87 & - \\
\hline Timbermen and lumbermen & - & - & - & - & - & - & - & 0.56 \\
\hline
\end{tabular}

a Proportion exposed to agent is zero.

Table 3. Results of risk estimates for laundry and dry cleaning workers and metal-plating workers. [NEC = number of exposed cases, RR $=$ observed relative risk, $95 \% \mathrm{Cl}=$ confidence interval, $\mathrm{RR}_{\mathrm{HB} 1}=$ posterior relative risk of hierarchical Bayesian $(\mathrm{HB}) \mathrm{model} 1, \mathrm{Crl}=\mathrm{credible}$ interval, $\mathrm{RR}_{\mathrm{HB} 2}=$ posterior relative risk of hierarchical Bayesian model 2].

\begin{tabular}{|c|c|c|c|c|c|c|c|}
\hline \multirow[t]{2}{*}{ Job title } & \multirow{2}{*}{$\begin{array}{l}\text { Exposed } \\
\text { workers } \\
\text { (N) }\end{array}$} & \multirow[t]{2}{*}{$\mathrm{RR}$} & \multirow[t]{2}{*}{$95 \% \mathrm{Cl}$} & \multicolumn{2}{|c|}{ Observed risk estimates } & \multicolumn{2}{|c|}{ Posterior risk estimates } \\
\hline & & & & $\mathrm{RR}_{\mathrm{HB} 1}$ & $95 \% \mathrm{Crl}$ & $\mathrm{RR}_{\mathrm{HB} 2}$ & $95 \% \mathrm{Crl}$ \\
\hline \multicolumn{8}{|l|}{ Laundry and dry cleaning workers } \\
\hline Pukkala, 1995 (28) & 6 & 1.11 & 0.41 .2 .42 & 1.41 & $0.91-2.17$ & 1.40 & $1.00-1.95$ \\
\hline Pukkala, 1995 (31) & 1 & 1.10 & $0.01-6.12$ & 1.43 & $0.88-1.43$ & 1.41 & $0.99-2.01$ \\
\hline Norell et al, 1986 (34) & 16 & 1.0 & $0.6-1.5$ & 1.21 & $0.86-1.70$ & 1.27 & $0.94-1.69$ \\
\hline Lynge \& Thygesen, 1990 (56) a & 13 & 1.40 & $0.74-2.39$ & 1.29 & $0.88-1.88$ & 1.24 & $0.91-1.69$ \\
\hline Lynge \& Thygesen, 1990 (56) ${ }^{b}$ & 9 & 2.37 & $1.08-4.50$ & 1.46 & $0.97-2.20$ & 1.31 & $0.96-1.84$ \\
\hline Ruder et al, 1994 (57) & 12 & 2.03 & $1.1-3.5$ & 1.60 & $1.09-2.36$ & 1.49 & $1.09-2.06$ \\
\hline Blair et al, 1990 (58) & 15 & 1.2 & $0.7-1.9$ & 1.34 & $0.93-1.90$ & 1.36 & $1.01-1.82$ \\
\hline Brown \& Kaplan, 1987 (59) & 11 & 1.72 & $0.86-3.10$ & 1.66 & $1.11-2.46$ & 1.63 & $1.19-2.23$ \\
\hline Aggregated risk estimates & & & & 1.42 & $1.05-1.93$ & 1.40 & $1.12-1.75$ \\
\hline \multicolumn{8}{|l|}{ Metal-plating workers } \\
\hline Pukkala, 1995 (28) & 12 & 3.54 & $1.83-6.19$ & 2.41 & $1.20-3.89$ & 2.35 & $1.53-3.65$ \\
\hline Pukkala, 1995 (31) & 1 & 1.2 & $0.02-6.68$ & 1.95 & $1.05-3.59$ & 2.13 & $1.29-3.47$ \\
\hline Coggon et al, 1986 (35) & 7 & 1.6 & $0.6-4.3$ & 2.14 & $1.22-3.70$ & 2.37 & $1.47-3.77$ \\
\hline Pickle \& Gottliem, 1980 (36) & 5 & 1.23 & $0.34-4.40$ & 2.05 & $1.11-3.73$ & 2.31 & $1.38-3.84$ \\
\hline Pang et al, 1996 (62) & 1 & 0.91 & $0.02-5.09$ & 1.94 & $1.04-3.56$ & 2.12 & $1.28-3.46$ \\
\hline Takahashi \& Okubo, 1990 (63) & 1 & 0.37 & $0.01-2.08$ & 1.90 & $1.01-3.50$ & 2.10 & $1.27-3.42$ \\
\hline Aggregated risk estimates & & & & 1.96 & $1.15-3.29$ & 2.11 & $1.33-3.35$ \\
\hline
\end{tabular}

a Estimates for women.

b Estimates for men.

In a Bayesian analysis, posterior estimates (eg, a posterior mean, a posterior median, and a posterior mode) for a parameter require a prior probability distribution in addition to data. A Bayesian analogue of a frequentist confidence interval is called a credible interval $(\mathrm{CrI})$, which is a posterior probability interval and also includes knowledge of a prior probability distribution in addition to data $(110,111)$.

In the hierarchical Bayesian models, Markov chain Monte Carlo (MCMC) methods were used, constructing two chains starting with different initial values by Gibbs sampling (112) using chains simulated by WinBUGS 
software (113). The convergences of the chains were assessed by examining Monte-Carlo errors and GelmanRubin statistics (114). The WinBUGS program, version 1.3, being freely available from http://www.mrc-bsu. cam.ac.uk/bugs/, was used in the hierarchical Bayesian models. Stata 8 for Windows was used in the non-Bayesian random effects models (115).

In this paper, we have used two kinds of hierarchical Bayesian models, HB1 and HB2 models, for the meta-analysis. We used different prior probability distributions for two parameters to consider the effects on the results. Details of the models have been published elsewhere (116).

The results of the hierarchical Bayesian models for meta-analysis were based on 200000 iterations with 20000 burn-in iterations and two chains in both the HB1 and HB2 models. We calculated antilogs of posterior medians as meta-relative risks, since the posterior me- dian is preferable over the posterior mean in preserving the antilog transformation.

\section{Results}

The observed study-specific relative risk estimates and the posterior estimates for two job titles, laundry and dry cleaning workers and metal-plating workers, on the basis of the HB1 and HB2 models, are shown in table 3 (see page 328). Only one observed risk estimate for laundry and dry cleaning workers failed to exceed unity. The study-specific posterior risk estimates for both laundry and dry cleaning workers and metal-plating workers seemed to shrink towards the aggregated mean.

Job title results of the random effects models and the hierarchical Bayesian models are shown in table 4.

Table 4. Results of the random effects (RE) models and hierarchical Bayesian (HB) models 1 and 2 for the job titles $\left(\mathrm{MRR}_{\mathrm{RE}}=\mathrm{meta}\right.$-relative risk in the RE models, $95 \% \mathrm{Cl}=95 \%$ confidence interval, $\mathrm{MRR}_{\mathrm{HB} 1}=$ meta-relative risk in hierachical Bayesian $\mathrm{model} 1,95 \% \mathrm{Crl}=95 \%$ credible interval, $\mathrm{MRR}_{\mathrm{HB} 2}=$ meta-relative risk in hierarchical Bayesian model 2).

\begin{tabular}{|c|c|c|c|c|c|c|c|}
\hline \multirow[t]{3}{*}{ Job title } & \multirow{3}{*}{$\begin{array}{c}\text { Exposed } \\
\text { workers } \\
(\mathrm{N})\end{array}$} & \multicolumn{6}{|c|}{ Aggregated estimates } \\
\hline & & \multicolumn{2}{|c|}{ RE models } & \multicolumn{4}{|c|}{ HB models } \\
\hline & & $\mathrm{MRR}_{\mathrm{RE}}$ & $95 \% \mathrm{Cl}$ & $\mathrm{MRR}_{\mathrm{HB} 1}$ & $95 \% \mathrm{Crl}$ & $\mathrm{MRR}_{\mathrm{HB} 2}$ & $95 \% \mathrm{Crl}$ \\
\hline Asphalt workers & 50 & 1.25 & $0.69-2.26^{a}$ & 1.17 & $0.83-1.66$ & 1.14 & $0.91-1.43$ \\
\hline Bench carpenters & 5 & 0.74 & $0.24-1.72$ & 0.91 & $0.54-1.53$ & 0.95 & $0.70-1.26$ \\
\hline Bricklayers & 32 & 0.64 & $0.44-0.93$ & 0.77 & $0.52-1.13$ & 0.85 & $0.73-1.24$ \\
\hline Cabinetmakers & 39 & 0.93 & $0.67-1.30$ & 0.95 & $0.62-1.45$ & 0.95 & $0.64-1.10$ \\
\hline Cement workers & 76 & 0.91 & $0.72-1.15$ & 0.98 & $0.67-1.45$ & 0.94 & $0.73-1.21$ \\
\hline Concrete shutters & 45 & 0.77 & $0.33-1.79$ & 0.90 & $0.60-1.34$ & 0.91 & $0.71-1.17$ \\
\hline Construction carpenters & 174 & 0.81 & $0.67-0.97$ & 0.84 & $0.61-1.16$ & 0.86 & $0.67-1.09$ \\
\hline Construction workers & 116 & 1.11 & $0.89-1.38$ & 1.00 & $0.75-1.32$ & 0.99 & $0.84-1.19$ \\
\hline Electric machine operators & 21 & 0.98 & $0.62-1.55$ & 0.98 & $0.66-1.45$ & 0.97 & $0.79-1.21$ \\
\hline Farmers & $>1746^{b}$ & 0.88 & $0.77-1.01^{c}$ & 0.89 & $0.72-1.10$ & 0.90 & $0.77-1.05$ \\
\hline Fitters and assemblers & 15 & 1.36 & $0.76-2.24$ & 1.01 & $0.72-1.34$ & 1.04 & $0.79-1.40$ \\
\hline Foundry workers & $>90^{d}$ & 1.02 & $0.81-1.27$ & 1.10 & $0.70-1.75$ & 0.99 & $0.79-1.23$ \\
\hline Laundry and dry cleaning workers & 83 & 1.41 & $1.13-1.76$ & 1.42 & $1.05-1.93$ & 1.40 & $1.12-1.75$ \\
\hline Machine and engine mechanics & 95 & 1.34 & $0.92-1.94$ & 1.25 & $0.89-1.77$ & 1.20 & $0.95-1.53$ \\
\hline Metal-plating workers & 27 & 2.04 & $1.17-3.55$ & 1.96 & $1.15-3.29$ & 2.11 & $1.33-3.35$ \\
\hline Metal-smelting furnacemen & 214 & 1.15 & $0.99-1.33$ & 1.10 & $0.81-1.49$ & 1.07 & $0.84-1.37$ \\
\hline Miners & 156 & 1.07 & $0.89-1.28$ & 1.02 & $0.73-1.39$ & 1.01 & $0.79-1.30$ \\
\hline Painters & 255 & 1.13 & $0.87-1.48^{e}$ & 1.11 & $0.83-1.50$ & 1.10 & $0.87-1.39$ \\
\hline Plywood-fiberboard workers & 21 & 1.38 & $0.87-2,17$ & 1.22 & $0.73-2.05$ & 1.18 & $0.76-1.86$ \\
\hline Printers-pressmen & 183 & 1.19 & $0.97-1.46$ & 1.21 & $0.91-1.60$ & 1.21 & $0.99-1.48$ \\
\hline Sawyers & 47 & 4,13 & $0.14-123^{\dagger}$ & 1.03 & $0.64-1.67$ & 0.94 & $0.66-1.36$ \\
\hline Sheet-metal workers & 17 & 1.03 & $0.61-1.74$ & 1.00 & $0.65-1.54$ & 1.02 & $0.77-1.33$ \\
\hline Smiths & 1 & 1.70 & $0.02-9.46$ & 1.14 & $0.62-2.07$ & 1.14 & $0.82-1.58$ \\
\hline Stone cutters & 5 & 0.77 & $0.27-1.76$ & 0,91 & $0.55-1.51$ & 0.91 & $0.69-1.20$ \\
\hline Timbermen and lumbermen & 24 & 1.01 & $0.63-1.61$ & 0.97 & $0.66-1.42$ & 0.97 & $0.78-1.22$ \\
\hline Turners and toolmakers & 21 & 0.69 & $0.44-1.08$ & 0.93 & $0.58-1.46$ & 1.08 & $0.77-1.46$ \\
\hline Wood-working machine operators & 241 & 0.98 & $0.85-1.13$ & 0.95 & $0.71-1.26$ & 0.95 & $0.77-1.16$ \\
\hline
\end{tabular}

\footnotetext{
a Test of heterogeneity: $P=0.061$.

${ }^{b}$ Missing from two studies.

c Test of heterogeneity: $P<0.001$.

d Missing from one study.

e Test of heterogeneity: $P=0.002$.

$\mathrm{f}$ Test of heterogeneity: $P=0.023$.
} 
We addressed between-study heterogeneity by using random effects models. Testing heterogeneity with a $\chi^{2}$ test by job title, we found significant heterogeneity for the studies addressing asphalt workers, farmers, painters, and sawyers. Publication bias was suspected only for the studies addressing metal-plating workers, using Begg's and Egger's tests for publication bias.

The meta-relative risks exceeded unity for 12 of the 27 job titles in all of the meta-analyses, including the non-Bayesian and Bayesian models. In the random effects models, the meta-relative risks exceeded unity for 16 job titles. For 3 job titles (metal-plating workers, laundry and dry cleaning operators, and printers and pressmen), the meta-relative risks were higher in one or the other two HB models than in the random effects models. The meta-relative risks, which were less than unity, were smaller in the HB models than in the random effects model for woodworking machine operators only.

The studies addressing laundry and dry cleaning workers were associated with an excess risk of pancreatic cancer in the random effects model with a metarelative risk of 1.41 [95\% confidence interval (95\% CI) 1.13-1.76], based on eight standardized incidence ratio (SIR) or standardized mortality ratio (SMR) risk estimates. In the HB1 and HB2 models, the meta-relative risks (MRR) for laundry and dry cleaning were 1.42 and 1.40 , and the $95 \%$ credible intervals (CrI) were 1.03 1.93 and $1.12-1.75$, respectively. Excesses were found for the studies on metal-plating workers in the random effects model [MRR 2.04, 95\% CI 1.17-3.55; 1 odds ratio (OR), 3 SIR or SMR, and 2 RR risk estimates), in the HB1 model (MRR 1.96, 95\% CrI 1.15-3.29), and in the HB2 models (MRR 2.11, 95\% CrI 1.33-3.35). Excess risks were found for the studies on printers or pressmen in the random effects model (MRR 1.19, 95\% CI 0.97-1.46; 1 OR, 9 SIR or SMR, and 2 RR risk

Table 5. Results of hierarchical Bayesian models 1 and 2 for occupational agents $\left(\mathrm{MRR}_{\mathrm{HB} 1}=\right.$ meta-relative risk in hierarchical Bayesian model 1, 95\% Crl $=95 \%$ credible interval, $\mathrm{MRR}_{\mathrm{HB} 2}=$ meta-relative risk in hierarchical Bayesian model 2)

\begin{tabular}{|c|c|c|c|c|}
\hline Agent & $\mathrm{MRR}_{\mathrm{HB} 1}$ & $95 \% \mathrm{Crl}$ & $\mathrm{MRR}_{\mathrm{HB} 2}$ & $95 \% \mathrm{Crl}$ \\
\hline $\begin{array}{l}\text { Aliphatic and alicyclic } \\
\text { hydrocarbon solvents }\end{array}$ & 1.11 & $0.65-1.92$ & 1.10 & $0.80-1.52$ \\
\hline $\begin{array}{l}\text { Chlorinated hydrocarbon } \\
\text { compounds }\end{array}$ & 2.03 & $0.99-4.08$ & 2.21 & $1.31-3.68$ \\
\hline Fungicides & 1.09 & $0.37-3.24$ & 0.91 & $0.45-1.93$ \\
\hline Insecticides & 1.53 & $0.33-7.07$ & 1.95 & $0.51-7.41$ \\
\hline $\begin{array}{l}\text { Nickel, nickel compounds, } \\
\text { chromium and chromium } \\
\text { compounds }\end{array}$ & 1.03 & $0.46-2.27$ & 1.05 & $0.61-1.81$ \\
\hline $\begin{array}{l}\text { Polycyclic aromatic } \\
\text { hydrocarbons }\end{array}$ & 1.13 & $0.78-1.63$ & 1.14 & $0.89-1.45$ \\
\hline Silica dust & 0.90 & $0.65-1.24$ & 0.90 & $0.72-1.11$ \\
\hline Wood dust & 0.96 & $0.69-1.33$ & 0.96 & $0.78-1.17$ \\
\hline
\end{tabular}

estimates) and in the HB1 and HB2 models (MRR 1.21, 95\% CrI 0.91-1.60, and MRR 1.21, 95\% CrI 0.99-1.48, respectively) and for plywood and fiberboard workers in the random effects model (MRR 1.38, 95\% CI 0.87-2.17) based on only two SMR risk estimates; the meta-relative risks in the HB1 and HB2 models were 1.22 and 1.18 , respectively. The meta-relative risks for machine and engine mechanics were 1.34, 1.25, and 1.20 in the random effects, HB1 and HB2 models, respectively. A decreasing risk was found for bricklayers and construction carpenters in all of the models, but the $95 \%$ credible intervals were wider than the $95 \%$ confidence intervals.

The occupational agent results of the hierarchical Bayesian models are shown in table 5. The meta-relative risks for pancreatic cancer exceeded unity for all of the agents except fungicides in the HB2 model and for silica and wood dust in both HB models. The credible intervals were generally narrower in the HB2 model than in the HB1 model. The highest meta-relative risks were found for chlorinated hydrocarbon compounds in the HB2 model, the meta-relative risk being 2.21 (95\% CrI 1.31-3.68). The meta-relative risk in the HB1 model was 2.03 , but the $95 \%$ credible interval $(0.99-4.08)$ was wider than in the HB2 model. The second-highest metarelative risks with wide $95 \%$ credible intervals were found for insecticides. In the HB2 model the meta-relative risk was 1.95 (95\% CrI 0.45-7.41), and in the HB1 model it was 1.53 (95\% CrI 0.33-7.07).

\section{Discussion}

The occupational agents in this study were selected on the basis of a previous meta-analysis (10), and some important occupational agents (eg, electromagnetic fields) might therefore have been left out. After selecting the agents, we chose job titles that, in Finland, represent exposure to these agents. These job titles may not hold true in all countries and may not have included some job titles that involve exposures to these agents.

For the hierarchical models, we selected only Bayesian methods because of the number of parameters $(28$ job titles, 8 agents, and 5 covariate parameters) in the model and the meta-analytic approach. Random effects models were used for each job title. In a comparison of the results of the $\mathrm{HB}$ and the random effects models, the meta-relative risks of the HB models were closer to unity even though the meta-relative risks of the random effects models were less or more than unity.

In aggregating observational studies, the main problems are the combinability and heterogeneity of studies, study selection bias, publication bias, ecological bias, and confounding. 


\section{Evidence}

We found excess risks for pancreatic cancer in respect to two job titles that were based on more than two input risk estimates in all of the models (random effects models and hierarchical Bayesian models), namely, laundry and dry cleaning workers and metal-plating workers. An excess risk was also found for printers and pressmen and plywood and fiberboard workers (including only two risk estimates) in all of the models. Laundry and dry cleaning workers, metal-plating workers, and printers and pressmen were likely to have been exposed to chlorinated hydrocarbon compounds, metal-plating workers also to chromium and nickel, and printers and pressmen to aliphatic and alicyclic hydrocarbon solvents. Likely agents for plywood and fiberboard workers were fungicides, insecticides, and wood dust. The results of the job titles were similar in the random effects and HB models. The biggest difference was in the relative risk estimates for sawyers. In the random effects model, the meta-relative risk was 4.13 (95\% CI 0.14-123), in the HB1 model it was 1.03 (95\% CI 0.64-1.67), and in the HB2 model it was 0.94 (95\% CI 0.66-1.36). Meta-relative risks were calculated from two heterogeneous studies $(52,99)$. The P-value for heterogeneity was 0.023 , and the observed risk estimate was 33.78 (95\% CI 0.44-188) as the SMR and 0.99 (95\% CI 0.76-1.27) as the SIR.

Chlorinated hydrocarbon compounds cover a variety of chemicals with industrial and research applications. Trichloroethylene, tetrachloroethylene (perchloroethylene), and 1,1,1-trichloroethane have mainly been employed in dry cleaning and metal degreasing. Dichloromethane (methylene chloride) is applied in metal degreasing and paint removing. Trichloroethylene also applies in the printing industry. Trichloroethylene and tetrachloroethylene have been classified as group 2A carcinogens (probably carcinogenic to humans) by the International Agency for Research on Cancer (IARC). Dichloromethane, carbon tetrachloride, and chloroform belong to group 2B carcinogens (possibly carcinogenic to humans).

In a meta-analysis (10) based on agent-specific studies, significant excess pancreatic cancer risks were found for occupational exposure to chlorinated hydrocarbon compounds and nickel. In this study, we found excess risks for chlorinated hydrocarbon compounds and insecticides in both the Bayesian hierarchical models, but not for occupational exposure to nickel. The credible intervals for insecticides were much wider than for chlorinated hydrocarbon compounds.

\section{Publication bias}

Publication bias was not likely in this study, as very few small studies expressly considered the occupational determinants of pancreatic cancer. Publication bias was suspected only for studies addressing metal-plating workers $(104,105)$.

\section{Selection of studies}

We used major databases and lists of references of the studies for identifying studies in any language. Unidentified studies were probably of low quality. We did not attempt to identify unpublished studies.

\section{Extraction}

We minimized extractor bias by the use of the formal extraction procedure, a group of extractors, and the central checking of extraction. The most relevant risk estimates were extracted.

\section{Combinability and heterogeneity}

Results for different exposure levels, time parameters of exposure, study types, methods, the time reference for job titles, and diagnostic specificities may not be readily combinable. We calculated all meta-relative risks, excluding the (proportional) studies with the lowest quality. All of the hierarchical Bayesian models included five covariates (study type, publication year, diagnosis of pancreatic cancer, country, and time reference for job title) to increase combinability through adjustment.

Random effects models were used to address between-population heterogeneity. Heterogeneity was found for risk estimates for asphalt workers, farmers, painters, and sawyers. The problem of combining results for different exposure levels and time parameters of exposure remained, as the exposure levels were unknown.

\section{Ecological bias}

Ecological or aggregated bias may emerge when grouplevel data are used for inferences on the individual level, since individual variation within groups is lost. Ecological bias on the average weakens relative risks (22).

A simple random effects meta-model is hierarchical with two levels, between-study heterogeneity representing aggregated or ecological bias, treated as in the preceding discussion.

In this study, the hierarchical Bayesian models operated on the following three levels: risk estimates from studies, job titles, and agents of exposure. A two-level hierarchical Bayesian meta-analysis was applied for clinical trials (117-120), but applications for observational data are rare. Hierarchical Bayesian methods in ecological studies, including ecological bias, have been discussed earlier $(108,109,121-123)$. Even a simple meta-analysis involves an ecological bias, as outcomes 
are not available on the individual level (124). Our meta-analysis involved studies of job titles with external agent data (FINJEM) with unknown extrapolability and unknown exposure levels, hence liable to exposure misclassification. Including country as a covariate in the hierarchical Bayesian models presumably reduced the misclassification bias.

\section{Concluding remarks}

The results of this meta-analysis suggest that occupational exposures to chlorinated hydrocarbon compounds increase the risk of pancreatic cancer, a result obtained in another meta-analysis of independent, agent-specific epidemiologic-specific studies. The hierarchical models used in this study are applicable in meta-analyses when studies addressing the agent(s) under study are lacking or very few, but several studies address job titles with potential exposure to these agents. A job-exposure matrix or a formal expert assessment system is necessary in such situations. Hierarchical models for meta-analyses involving durations and intensities of exposure to occupational agents from a job-exposure matrix should be developed.

\section{Acknowledgments}

The Finnish Work Environment Fund has supported this study.

\section{References}

1. Ferlay J, Bray F, Pisani P, Parkin DM. Globocan 2000: cancer incidence, mortality and prevalence worldwide, version 1.0. Lyon (France): IARC Press; 2001. IARC Cancer Base No. 5.

2. International Agency for Research on Cancer (IARC). Tobacco smoking. Lyon (France): IARC; 1986. Monographs on the Evaluation Carcinogenic Risks to Humans, volume 38.

3. Lowenfels AB, Maisonneuve P, Cavallini G, Ammann RW, Lankisch PG, Andersen JR, et al. Pancreatitis and the risk of pancreatic cancer. New Engl J Med. 1993;328(20):1433-7.

4. Huxley R, Ansary-Moghaddam A, Berrington de González A, Barzi F, Woodward M. Type-II diabetes and pancreatic cancer: a meta-analysis of 36 studies. Br J Cancer. 2005;92(6):207683.

5. Partanen T, Kauppinen T, Degerth R, Moneta M, Mearelli I, Ojajärvi A, et al. Pancreatic cancer in industrial branches and occupations in Finland. Am J Ind Med. 1994;25(1):851-66.

6. Ji BT, Silverman DT, Dosemici M, Dai Q, Gao YT, Blair A. Occupation and pancreatic cancer risk in Shanghai, China. Am J Ind Med. 1999;35(1):76-81.

7. Kernan GJ, Ji BT, Dosemici M, Silverman DT, Balbus J, Zahm $\mathrm{SH}$. Occupational risk factors for pancreatic cancer: a casecontrol study based on death certificates from 24 US States.
Am J Ind Med. 1999;36(2):260-70.

8. Alguacil J, Porta M, Benavides FG, Malats N, Kogevinas M, Fernández E, et al. PANKRAS II Study Group: occupational and pancreatic cancer in Spain: case-control study based on job titles. Int J Epidemiol. 2000;29(6):1004-13.

9. Alguacil J, Pollán M, Gustavsson P. Occupations with increased risk of pancreatic cancer in the Swedish population. Occup Environ Med. 2003;60(8):570-6.

10. Ojajärvi IA, Partanen TJ, Ahlbom A, Boffetta P, Hakulinen $\mathrm{T}$, Jourenkova N, et al. Occupational exposure and pancreatic cancer: a meta-analysis. Occup Environ Med. 2000;57(5):31624.

11. Hoppin JA, Tolbert PE, Holly EA, Brock JW, Korrick SA, Altshul LM, et al. Pancreatic cancer and serum organochlorine levels. Cancer Epidemiol Biomarkers Prev. 2000;9(2):199205.

12. Weiderpass E, Vainio H, Kauppinen T, Vasama-Neuvonen K, Partanen T, Pukkala E. Occupational exposures and gastrointestinal cancers among Finnish women. J Occup Environ Med. 2003;45(3):305-15.

13. McElvenny DM, Armstrong BG, Järup L, Higgins JP. Metaanalysis in occupational epidemiology: a review of practice. Occup Med. 2004;54(5):336-44.

14. Biggerstaff BJ, Tweedie RL, Mengersen KL. Passive smoking in the workplace: classical and Bayesian meta-analysis. Int Arch Occup Environ Health. 1994;66(4):269-77.

15. Tweedie RL, Scott DJ, Biggerstaff BJ, Mendersen KL. Bayesian meta-analysis, with application to studies of ETS and lung cancer. Lung Cancer. 1996;14 suppl 1:s171-94.

16. Wraith D, Mengersen K. Assessing the combined effect of asbestos exposure and smoking on lung cancer: a Bayesian approach. Stat Med. 2007;26(5):1150-69.

17. Kauppinen T, Partanen T, Degerth R, Ojajärvi A. Pancreatic cancer and occupational exposures. Epidemiology. 1995;6(5):498-502.

18. Pannett B, Coggon D, Acheson ED. A job-exposure matrix for use in population based studies in England and Wales. Br J Ind Med. 1985;42(11):777-83.

19. Alguacil J, Kauppinen T, Porta M, Partanen T, Malats N, Kogevinas M et al. Risk of pancreatic cancer and occupational exposures in Spain. Ann Occup Hyg. 2000;44(5):391-403.

20. Kauppinen T, Toikkanen J, Pukkala E. From cross-tabulations to multipurpose information systems: a new job-exposure matrix. Am J Ind Med. 1998;33(4):409-17.

21. Kogevinas M, 't Mannetje A, Cordier S, Ranft U, Gonzalez $\mathrm{CA}$, Vineis $\mathrm{P}$, et al. Occupation and bladder cancer among men in Western Europe. Cancer Causes Control. 2003;14(10):90714.

22. Gilks WR, Richardson S. Analysis of disease risks using ancillary risk factors, with application to job-exposure matrices. Stat Med. 1992;11(11):1443-63.

23. Witte JS, Greenland S, Haile RW, Bird CI. Hierarchical regression analysis applied to a study of multiple exposures and breast cancer. Epidemiology. 1994;5(6):612-21.

24. Witte JS, Greenland S, Kim L-L. Software for hierarchical modeling of epidemiologic data. Epidemiology. 1998;9(5):563-6.

25. Witte JS, Greenland S, Kim L-L, Arab L. Multilevel modeling in epidemiology with GLIMMIX. Epidemiology. 2000;11(6):684-8.

26. Breslow NE, Day NE. Statistical methods in cancer research, vol II: the design and analysis of cohort studies. Lyon (France): International Agency for Research on Cancer; 1987.

27. Engholm G, Englund A. Morbidity and mortality patterns in 
Sweden. Occup Med. 1995;10(2):261-8.

28. Pukkala E. Cancer risk by social class and occupation: a survey of 109,000 cancer cases among Finns of working age. Basel (Switzerland): S Karger AG; 1995.

29. Kauppinen T, Heikkilä P, Koskinen H, Ojajärvi A, Partanen T, Pukkala E, et al. Bitumihuuruille altistuneiden työntekijöiden syöpävaara [Cancer risk in workers exposed to bitumen fumes]. Helsinki: Finnish Work Environment Fund; 1996. Report no: 93011.

30. Minder CE, Beer-Porizek V. Cancer mortality of Swiss men by occupation, 1979-1982. Scand J Work Environ Health. 1992;18 suppl 3:1-27.

31. Hrubec Z, Blair AE, Roget E, Vaught J. Mortality risk by occupation among US veterans of known smoking status 1954-1980. Bethesda (MD): US Department of Health and Human Services; 1992. NIH Publication No 92-3407.

32. Olsen J, Sabroe S. A follow-up study of non-retired and retired members of the Danish Carpenter/Cabinet Makers' Trade Union. Int J Epidemiol. 1979;8(4):375-82.

33. Jakobsson K, Horstmann V, Welinder H. Mortality and cancer morbidity among cement workers. Br J Ind Med. 1993;50(3):264-72.

34. Norell S, Ahlbom A, Olin R, Erwald R, Jacobson G, LindbergNavier I, et al. Occupational factors and pancreatic cancer. $\mathrm{Br}$ J Ind Med. 1986;43(11):775-8.

35. Coggon D, Pannett B, Osmond C, Acheson ED. A survey of cancer and occupation in young and middle aged men, II: nonrespiratory cancers. Br J Ind Med. 1986;43(6):381-6.

36. Pickle LW, Gottlieb MS. Pancreatic cancer mortality in Louisiana. Am J Public Health. 1980;70(3):256-9.

37. Pietri F, Clavel F, Auquier A, Flamant R. Occupational risk factors for cancer of the pancreas: a case-control study. Br J Ind Med. 1990;47(3):425-8.

38. Törnqvist S, Norell S, Ahlbom A, Knave B. Cancer in the electric power industry. Br J Ind Med. 1986;43(3):212-3.

39. Fincham SM, Hanson J, Berkel J. Patterns and risks of cancer in farmers in Alberta. Cancer. 1992;69(5):1276-85.

40. Franceschi S, Barbone F, Bidoli E, Guarneri S, Serraino D, Talamini R, et al. Cancer risk in farmers: results from a multisite case-control study in north-eastern Italy. Int $\mathrm{J}$ Cancer. 1993;53(5):740-5.

41. Gambini GF, Mantovani C, Pira E, Piolatto PG, Negri E. Cancer mortality among rice growers in Novara province, Northern Italy. Am J Ind Med. 1997;31(4):435-41.

42. Kristensen P, Andersen A, Irgens LM, Laake P, Bye AS. Incidence and risk of cancer among men and women in Norwegian agriculture. Scand J Work Environ Health. 1996;22(1):14-26.

43. Mastrangelo G, Marzia V, Marcer G. Reduced lung cancer mortality in dairy farmers: is endotoxin exposure the key factor? Am J Ind Med. 1996;30(5):601-9.

44. Rafnsson V, Gunnarsdottir H. Mortality among farmers in Iceland. Int J Epidemiol. 1989;18(1):146-51.

45. Ronco G, Costa G, Lynge E. Cancer risk among Danish and Italian farmers. Br J Ind Med. 1992;49(4):220-5.

46. Wiklund K, Dich J. Cancer risks among male farmers in Sweden. Eur J Cancer Prev. 1995;4(1):81-90.

47. Burmeister LF. Cancer mortality in Iowa farmers, 1971-78. J Natl Cancer Inst. 1981;66(3):461-64.

48. Folsom AR, Zhang S, Sellers TA, Zheng W, Kushi LH, Cerhan JR. Cancer incidence among women living on farms: findings from the Iowa Women's Health Study. J Occup Environ Med. 1996;38(11):1171-6.

49. Waterhouse D, Carman WJ, Schottenfeld, Dridley G, McLean S. Cancer incidence in the rural community of Tecumesec,
Michigan: a pattern of increased lymphopoietic neoplasms. Cancer. 1996;77(4):763-70.

50. Costa G, Faggiano F, Lagorio S. Occupational mortality in Italy in the '80s. Rome: Instito Poligrafico e Zecca dello Stato; 1995.

51. Andjelkovich DA, Mathew RM, Richardson RB, Levine RJ. Mortality of iron foundry workers, I: overall findings. J Occup Med. 1990;32(6):526-40.

52. Sherson D, Svane O, Lynge E. Cancer incidence among foundry workers in Denmark. Arch Environ Health. 1991;46(2):7581.

53. Sorahan T, Faux AM, Cooke MA. Mortality among a cohort of United Kingdom steel foundry workers with special reference to cancers of the stomach and lung, 1946-90. Occup Environ Health. 1994;51(5):316-22.

54. Decoufle P, Wood DJ. Mortality patterns among workers in a gray iron foundry. Am J Epidemiol. 1979;109(6):667-75.

55. Rotimi C, Austin H, Delzell E, Day C, Macaluso M, Honda Y. Retrospective follow-up study of foundry and engine plant workers. Am J Ind Med. 1993;24(4):435-98.

56. Lynge E, Thygesen L. Primary liver cancer among women in laundry and dry-cleaning work in Denmark. Scand J Work Environ Health. 1990;16(2):108-12.

57. Ruder AM, Ward EM, Brown DP. Cancer mortality in female and male dry-cleaning workers. J Occup Med. 1994;36(8):86774.

58. Blair A, Stewart PA, Tolbert PE, Grauman D, Moran FX, Vaught J, et al. Cancer and other causes of death among a cohort of dry cleaners. Br J Ind Med. 1990;47(3):162-8.

59. Brown DP, Kaplan SD. Retrospective cohort mortality study of dry cleaner workers using perchloroethylene. J Occup Med. 1987;29(6):535-41.

60. Hansen ES. Mortality of auto mechanics. a ten-year follow-up. Scand J Work Environ Health. 1989;15(1):43-6.

61. Viadana E, Bross ID, Houten L. Cancer experience of men exposed to inhalation of chemicals or to combustion products. J Occup Med. 1976;18(12):787-92.

62. Pang D, Burges DC, Sorahan T. Mortality study of nickel platers with special reference to cancers of the stomach and lung, 1945-93. Occup Environ Med. 1996;53(10):714-7.

63. Takahashi K, Okubo T. A prospective cohort study of chromium plating workers in Japan. Arch Environ Health. 1990;45(2):107-11.

64. Carta P, Cocco PL, Flore C, Pau M, Grussu M, Cherchi P. Mortality among primary aluminium foundry workers in Sardinia. Med Lav. 1992;83(5):530-5.

65. Costantino JP, Redmond CK, Bearden A. Occupationally related cancer risk among coke oven workers: 30 years of follow-up. J Occup Environ Med. 1995;37(5):597-604.

66. Franco F, Chellini E, Seniori Costantini A, Gioia A, Carra G, Paolinelli F, et al. Mortality in the coke oven plant of Carrara, Italy. Med Lav. 1993;84(6):443-7.

67. Gibbs GW, Amsel J, Soden K. A cohort mortality study of cellulose triacetate-fiber workers exposed to methylene chloride. J Occup Environ Med. 1996;38(7):693-7.

68. Gustavsson P, Reuterwall C. Mortality and incidence of cancer among Swedish gas workers. Br J Ind Med. 1990;47(3):16974.

69. Kjuus H, Andersen A, Langård S, Knudsen KE. Cancer incidence among workers in the Norwegian ferroalloy industry. $\mathrm{Br}$ J Ind Med. 1986;43(4):227-36.

70. Milham SJ. Mortality in aluminum reduction plant workers. J Occup Med. 1979;21(7):475-80.

71. Mur JM, Moulin JJ, Meyer-Bisch C, Massin N, Moulin JJ, 
Cavelier C, et al. Mortality of aluminum reduction plant workers in France. Int J Epidemiol. 1987;16(2):257-64.

72. Rockette HE, Arena VC. Mortality studies of aluminum reduction plant workers: potroom and carbon department. J Occup Med. 1983;25(7):549-57.

73. Spinelli JJ, Band PR, Svirchev LM, Gallagher RP. Mortality and cancer incidence in aluminum reduction plant workers. J Occup Med. 1991;33(11):1150-5.

74. Swaen GM, Slangen JJ, Volovics A, Hayes RB, Scheffers T, Sturmans F. Mortality of coke plant workers in The Netherlands. Br J Ind Med. 1991;48(2):130-5.

75. Andersen A, Dahlberg BE, Magnus K, Wannag A. Risk of cancer in the Norwegian aluminium industry. Int $\mathrm{J}$ Cancer. 1982;29(3):295-8.

76. Tokudome S, Kuratsune M. A cohort study on mortality from cancer and other causes among workers at a metal refinery. Int J Cancer. 1976;17(3):310-7.

77. Selden AI, Westberg HB, Axelson O. Cancer morbidity in workers at aluminum foundries and secondary aluminum smelters. Am J Ind Med. 1997;32(5):467-77.

78. Cocco PL, Carta P, Belli S, Picchiri GF, Flore MV. Mortality of Sardinian lead and zinc miners: 1960-88. Occup Environ Med. 1994;51(10):674-82

79. Armstrong BK, McNulty JC, Levitt LJ, Williams KA, Hobbs MS. Mortality in gold and coal miners in Western Australia with special reference to lung cancer. $\mathrm{Br} \mathrm{J}$ Ind Med. 1979;36(3):199-205.

80. Kinlen LJ, Willows AN. Decline in the lung cancer hazard: a prospective study of the mortality of iron ore miners in Cumbria. Br J Ind Med. 1988;45(4):219-24.

81. Lawler AB, Mandel JS, Schuman LM, Lubin JH. A retrospective cohort mortality study of iron ore (hematite) miners in Minnesota. J Occup Med. 1985;27(7):507-17.

82. Roscoe RJ, Deddens JA, Salvan A, Schnorr TM. Mortality among Navajo uranium miners. Am J Public Health. 1995;85(4):535-40.

83. Belli S, Comba P, Germani D, Grignoli M, Lagorio S, Paganoni R. Mortality among lead-zinc miners in Val Seriana. Med Lav. 1989;80(6):467-78.

84. Stille WT, Tabershaw IR. The mortality experience of upstate New York talc workers. J Occup Med. 1982;24:480-4.

85. Swaen GM, Meijers JM, Slangen JJ. Risk of gastric cancer in pneumoconiotic coal miners and the effect of respiratory impairment. Occup Environ Med. 1995;52(9):606-10.

86. Tarchi M, Orsi D, Comba P, De Santis M, Pirastu R, Battista $\mathrm{G}$, et al. Cohort mortality study of rock salt workers in Italy. Am J Ind Med. 1994;25(2):251-6.

87. Tomasek L, Darby SC, Swerdlow AJ, Placek V, Kunz E. Radon exposure and cancers other than lung cancer among uranium miners in West Bohemia. Lancet. 1993;341(8850):919-23.

88. Une H, Esaki H, Osajima K, Ikui H, Kodama K, Hatada K. A prospective study on mortality among Japanese coal miners. Ind Health. 1995;33(2):67-76.

89. Brown DP, Kaplan SD, Zumwalde RD, Kaplowits M, Archer WE. Retrospective cohort mortality study of underground gold mine workers. Cancer Res Monogr. 1986;2:335-50.

90. Guberan E, Usel M, Raymond L, Tissot R, Sweetnam PM. Disability, mortality, and incidence of cancer among Geneva painters and electricians: a historical prospective study. Br J Ind Med. 1989;46(1):16-23.

91. Matanoski GM, Stockwell HG, Diamond EL, Haring-Sweeney M, Joffe RD, Mele LM et al. A cohort mortality study of painters and allied tradesmen. Scand J Work Environ Health. 1986;12(1):16-21.
92. Bethwaite PB, Pearce N, Fraser J. Cancer risks in painters: study based on the New Zealand Cancer Registry. Br J Ind Med. 1990;47(11):742-6.

93. Demers PA, Boffetta P, Kogevinas M, Blair A, Miller BA, Robinson $\mathrm{CF}$, et al. Pooled reanalysis of cancer mortality among five cohorts of workers in wood-related industries. Scand J Work Environ Health. 1995;21(3):179-190.

94. Leon DA. Mortality in the British printing industry: a historical cohort study of trade union members in Manchester. Occup Environ Med. 1994;51(2):79-86.

95. Lynge E, Rix BA, Villadsen E, Andersen I, Hink M, Olsen E, et al. Cancer in printing workers in Denmark. Occup Environ Med. 1995;52(11):738-44.

96. Paganini-Hill A, Glazer E, Henderson BE, Ross RK. Causespecific mortality among newspaper web pressmen. J Occup Med. 1980;22(8):542-4.

97. Malker HS, Gemne G. A register-epidemiology study on cancer among Swedish printing industry workers. Arch Environ Health. 1987;42(2):73-82

98. Michaels D, Zoloth SR, Stern FB. Does low-level lead exposure increase risk of death?: a mortality study of newspaper printers. Int J Epidemiol. 1991;20(4):978-83.

99. Hertzman C, Teschke K, Ostry A, Hershler R, Dimich-Ward H, Kelly S, et al. Mortality and cancer incidence among sawmill workers exposed to chlorophenate wood preservatives. Am J Public Health. 1997;87(1):71-9.

100. Becker N, Chang Claude J, Frentzel Beyme R. Risk of cancer for arc welders in the Federal Republic of Germany: results of a second follow up (1983-8). Br J Ind Med. 1991;48(10):67583.

101. Kawachi I, Pearce N, Fraser J. A New Zealand Cancer Registry-based study of cancer in wood workers. Cancer. 1989;64(5):2607-13.

102. Stellman SD, Garfinkel L. Cancer mortality among woodworkers. Am J Ind Med. 1984;5(5):343-57.

103. Barthel E, Dietrich M. Retrospective cohort study of cancer morbidity in furniture makers exposed to wood dust. Z Gesamte Hyg. 1989;35(5):279-81.

104. Kauppinen TP, Mutanen PO, Seitsamo JT. Magnitude of misclassification bias when using a job-exposure matrix. Scand J Work Environ Health. 1992;18(2):105-12.

105. DerSimonian R, Laird N. Meta-analysis in clinical trials. Control Clin Trials. 1989;7(3):177-88.

106. Begg CB, Mazumdar M. Operating characteristics of a rank correlation test for publication bias. Biometrics. 1994;50(4):1088-101.

107. Egger M, Smith GD, Schneider M, Minder C. Bias in metaanalysis detected by a simple, graphical test. Br Med J. 1997;315(7109):629-34.

108. Richardson S, Best N. Bayesian hierarchical models in ecological studies of health-environment effects. Environmetrics. 2003;14(2):129-47.

109. Wakefield J. Ecological inference for $2 \times 2$ tables. J R Statist Soc A. 2004;167:385-445.

110. Congdon P. Applied Bayesian modelling. Chichester: Wiley; 2003.

111. Gelman a, Carlin JB, Stern HS, Rubin DB. Bayesian data analysis. 2nd ed. Boca Raton (FL): Chapman \& Hall/CRC; 2003.

112. Gilks WR, Richardson S, Spiegelhalter DJ. Markov Chain Monte Carlo in practice. London: Chapman \& Hall; 1996.

113. Spiegelhalter D, Thomas A, Best N. WinBUGS user manual, version 1.3. Cambridge (UK): Medical Research Council Biostatistics Unit; 1999. 
114. Brooks SP, Gelman A. Alternative methods for monitoring convergence of iterative simulations. J Comput Graphical Stat. 1998;7:434-55.

115. Sharp S, Sterne J. Meta-analysis. Stata Tech Bull Repr. 1997;7:100-6.

116. Ojajärvi A. Occupational determinants of pancreatic cancer [dissertation]. Helsinki: Finnish Institute of Occupational Health, University of Helsinki; 2006. People and Work Research Reports 75.

117. Smith TC, Speigelhalter DJ, Thomas A. Bayesian approaches to random-effects meta-analysis: a comparative study. Stat Med. 1995;14(24):2685-99.

118. DuMouchel WH. Bayesian meta-analysis. In: Berry DA, editor, Statistical methods in pharmaceutical sciences, New York (NY): Marcel Dekker; 1990. p 509-29.

119. Abrams K, Sanso B. Approximate Bayesian inference for random effects meta-analysis. Stat Med. 1998;17(2):201-18.
120. Normand ST. Meta-analysis: formulating, evaluating, combining, and reporting. Stat Med. 1999;18(3):321-59.

121. Morgenstern H. Ecologic studies. In: Rothman KJ, Greenland S, editors. Modern epidemiology. Philadelphia (PA): Lippincott-Raven; 1998. p 459-80.

122. Greenland S. Ecological versus individual-level sources of bias in ecological health effects. Int J Epidemiol. 2001;30(6):134350.

123. Jackson C, Best N, Richardson S. Improving ecological inference using individual-level data. Stat Med. 2006;25(12):213659.

124. Greenland S. Meta analysis. In: Rothman KJ, Greenland S, editors. Modern epidemiology. Philadelphia (PA): LippincottRaven; 1998. p 643-73.

Received for publication: 28 August 2006 